SYlWia KarolaK

Uniwersytet im. Adama Mickiewicza w Poznaniu

\title{
„Luki historii domagają się domknięcia, a przede wszystkim opisania”. Literatura węgierska wobec Zagłady w latach 1944-1948
}

Piotrowiak-Junkiert Kinga (2020), Od idylli do ironii. Literatura wegierska wobec Zagłady w latach 1944-1948, Wydawnictwo Naukowe UAM, Poznań.

Kinga Piotrowiak Junkiert, autorka Od idylli do ironii. Literatura wegierska wobec Zagłady w latach 1944-1948, ukończyła filologię polską i węgierską, jest też cenioną tłumaczką literatury węgierskiej (Röhrig 2016; Kertész 2016; Halasi 2017). Kompetencje te pozwalają jej badać nieeksplorowane wcześniej przez (nie tylko polskich) literaturoznawców obszary literatury węgierskiej w oparciu o własne kwerendy badawcze i lekturę $\mathrm{w}$ oryginale, a więc bez ograniczania się do tego tylko, co już zostało przetłumaczone przez innych czy doczekało się recepcji na Węgrzech (co okaże się kluczowe w kontekście recenzowanej pracy). Pisze więc Piotrowiak-Junkiert o literaturze węgierskiej z jej wnętrza, ze środka dyskursu - bezpośrednio. Zna też doskonale literaturę polską, co stanowi niezaprzeczalny walor i co wyraźnie rezonuje w jej pracach: wydanej w 2014 roku publikacji poświęconej twórczości węgierskiego noblisty Świadomość zwrócona przeciwko sobie samej. Imre Kertész wobec Zagłady oraz analizowanej tutaj Od idylii do ironii.... Obie książki wypełniają puste miejsca w polskiej refleksji literaturoznawczej, stanowiąc przede wszystkim punkt wyjścia dla badań o charakterze komparatystycznym.

Dzięki przywołanym powyżej pracom wiemy, że „do 2002 roku nie wydano na Węgrzech ani jednej pracy naukowej dotyczącej doświadczenia żydowskiego 
czasu II wojny światowej w literaturze węgierskiej” (Piotrowiak-Junkiert 2020: 10). Ponadto, co szczególnie istotne, lista tych pisarzy, którzy zaczęli funkcjonować w świadomości literackiej po Noblu dla Kertésza, jest zamknięta i krótka, bo obejmuje zaledwie pięć nazwisk, co stanowi, jak pisze autorka: „owoc niezwykle skutecznych zabiegów politycznych, najpierw stalinowskich, a później komunistycznych” (Piotrowiak-Junkiert 2020: 11). Pisarze pochodzenia żydowskiego byli pomijani przez krytykę (jak Teréz Rudnóy, którą odkrywamy dzięki pracy Piotrowiak-Junkiert) albo (co dobrze obrazuje przypadek Miklósa Radnótiego, jednego z głównych bohaterów Od idylli do ironii...) mówiono o ich doświadczeniu tak, jakby nie byli Żydami, jakby nie opowiadali o Zagładzie, ale o wojnie i doświadczeniu węgierskim w ogóle. Przykłady te każą szukać punktów wspólnych $\mathrm{z}$ recepcją literatury poświęconej Zagładzie, jakiej (nie) dokonano w okresie Polski Ludowej, a także dominacją (choćby w nauczaniu szkolnym) utworów pisanych z perspektywy świadka nie-Żyda.

Analizowana tutaj praca obejmuje pozornie krótki okres, bo „tylko” lata bezpośrednio powojenne 1944-1948. Używam słowa „pozornie”, bo to, co w ujęciu buchalteryjnym jawi się jako zaledwie pięć lat, jest w przypadku pamięci o Zagładzie i reakcji na nią (także literackiej) czasem o znaczeniu kluczowym. To moment zakończenia wojny, okres, w którym ci, którzy ocaleli, podejmują pierwsze próby opisu doświadczenia wojennego. W warunkach polskich był to szczególny czas. Wtedy, w drugiej połowie lat czterdziestych, możliwe było jeszcze opowiadanie o wojnie, wydawanie książek. Dopiero krzepła cenzura swą działalność w 1946 roku rozpoczynał i wytyczne formułował Główny Urząd Kontroli Prasy, Publikacji i Widowisk. Właśnie lata 1944-1948 Michael C. Steinlauf wyodrębnia jako okres osobny i nazywa czasem „pamięci poranionej” (Steinlauf 2001: 59-78). Nowy, komunistyczny rząd deklaratywnie odcinał się od antysemityzmu, jednocześnie jednak doszło do pogromów w Rzeszowie, Przemyślu, Krakowie (1945) i w Kielcach (1946). Koniec lat czterdziestych przyniósł szczeciński zjazd literatów (1949), podczas którego uznano socrealizm za oficjalnie obowiązującą metodę twórczą. W tak pomyślanym uniwersum, w nowej Polsce nie było miejsca na literaturę, która eksponowałaby tak żydowskie doświadczenie wojny, jak i II wojnę światową w ogóle.

Lata 1944-1948 to czas bardzo brzemienny w skutki także jeśli chodzi o sytuację Żydów na Węgrzech. Wspomnieć trzeba, że wojna rozpoczęła się w tym kraju w zasadzie w roku 1944, co nie oznacza jednak, że od 1939 roku Żydzi węgierscy mogli czuć się bezpiecznie'. Jak pisze Piotrowiak-Junkiert,

1 Szerzej o sytuacji Żydów na Węgrzech od 1939 do 1944 roku pisze Piotrowiak-Junkiert w analizowanej pracy. Zob. Piotrowiak-Junkiert 2020: 19. 
krótko po wojnie dla pisarzy pochodzenia żydowskiego ogłoszono silencium: zakaz druku oraz podejmowania pracy w kulturze (Piotrowiak-Junkiert 2020: 11). Choć oficjalnie potępiano zbrodnie wojenne, antysemityzm narastał w 1946 roku doszło do pogromów w Békéscsabie i w Miszkolcu. To także okres formułowania głównych założeń nowej polityki historycznej: Zagłada stała się tematem niechcianym - nie pasowała do powojennej wizji nowego państwa. Podejmowane wówczas jednostkowe próby przełamania milczenia okazywały się nieskuteczne (Piotrowiak-Junkiert 2020: 87). W tym właśnie czasie powstają utwory, które analizuje Piotrowiak-Junkiert. Naturalnym kontekstem, do którego odwołuje się czytelnik Od idylli do ironii..., jest kontekst polski - namysł nad tym, co zostało napisane i opublikowane na rodzimym gruncie. Recepcja tych utworów w kontekście wydarzeń Zagłady to już inna sprawa, której poświęcono osobne publikacje.

W dalszej części Wstępu autorka zwraca uwagę na zmiany, jakie na Węgrzech przynosi rok 1956, który okazuje się przełomowy „mimo klęski węgierskiego Października":

Proces powolnego, ale konsekwentnego przywoływania tematu żydowskiego, połączony z przybierającą na sile i zauważalną w każdej dziedzinie sztuki odwilżą kulturalną epoki Jánosa Kádára, doprowadził do piku wydawniczego w latach 7o. Ukazały się wtedy, jedna po drugiej, książki zaliczane dzisiaj do ścisłego kanonu powojennej literatury węgierskiej podejmującej temat Zagłady (Piotrowiak-Junkiert 2020: 14).

Jak czytamy w analizowanej pracy, to właśnie w czasie tej reprezentacyjnej nadwyżki ukazuje się Los utracony (1975), jednak - podobnie jak inne publikacje - nie wywołuje dyskusji ani komentarzy literackich. Sytuacja nie zmieniła się także po transformacji ustrojowej. Jak pisze Piotrowiak-Junkiert, „do dzisiaj na Węgrzech nie ma ani osobnej katedry badań naukowych, programów studiów, wykładów, ani seminariów poświęconych historii czy literaturze żydowskiej” (Piotrowiak-Junkiert 2020: 16). Porównania do sytuacji polskiej literatury dotyczącej Zagłady m.in. w czasie „odwilży”, w latach siedemdziesiątych, osiemdziesiątych, na początku XXI wieku, wreszcie - dzisiaj, narzucają się z wielką siłą.

Zasadnicza część pracy składa się z ośmiu rozdziałów - każdy poświęcony został innemu autorowi i dziełu. Są to: pierwsza węgierska powieść obozowa Szabaduló asszonyok. A szabadság elsö 24 órája (Wyzwalające się kobiety. Pierwsze 24 godziny wolności) (wyd. 1946) Teréz Rudnóy, Razglednicák (serb. „pocztówki”) (1944, wyd. 1978) Miklósa Radnótiego (Radnóti 1980), Emberszag (Woń człowieka) (1945) Ernő Szépa (Szép 2017: 14-25), Ostromnapló (Dzienniki 
oblężenia) (1944-1945) i Márciustól márciusig (Od marca do marca) (wyd. 1947) Istvána Vasa, Egy halott álmaiból (Ze snów umarlej) (1945, wyd. 2000) Stefánii Mándy, diarystyka gettowa kobiet: Éva lányom (Moja córka Ewa) (1944, wyd. 2011²) Évy Heyman (1931-1944) i Kismama sárga csillaggal. Egy fiatalasszony naplója a német megszállástól 1945 júliusáig (Oczekując dziecka z żółtą gwiazdą. Dziennik młodej kobiety od zajęcia kraju do lipca 1945 roku) (1944-1945, wyd. 2015) Anny Dévényi Sándorné, oraz reportaż Lágerek népe (Narodzie lagrów) (1943-1945, wyd. 1947), dramat Voronyezs (Woroneż) (1944, wyd. 1948) i nowele frontowe Hábroús évek (Wojenne lata) (1943-1948, wyd. 1948) Istvána Örkényego (1912-1979)3. Utwory, po które sięga Piotrowiak-Junkiert, reprezentują różne rodzaje i gatunki literackie - są tutaj bukoliki, powieści, dzienniki, reportaż, dramat, nowele, proza poetycka. By o nich mówić, autorka uruchamia różne metodologie, m.in. perspektywę feministyczną, animal czy gender studies. W opisanych w pracy dziełach badaczka dostrzega: wysokie ambicje artystyczne, fantazję gatunkową, śmiałe wybory rytmiczne, wysmakowane koncepty, opisy erudycyjne i stylistyczne, wymagające dużej dyscypliny struktury poetologiczne (Piotrowiak-Junkiert 2020: 20). Odejście od obowiązku opisania ,jak było”, od dosłowności, faktografii na rzecz eksperymentu i inwencji artystycznej każe uznać pisarstwo to za fenomen. W Polsce takie decyzje podjęli nieliczni twórcy (Leopold Buczkowski, Stanisław Lem).

Ikoną myślenia o „czasie kamiennym” w Polsce stał się Tadeusz Różewicz i Tadeusz Borowski, operujący surowym stylem i eliptyczną składnią, na Węgrzech są to Radnóti i Pilinszky, którzy wybrali do opisania Zagłady topikę antyczną i heksametr (Radnóti) czy skomplikowaną symbolikę katastroficzną (Pilinszky). W tym zestawieniu widać także, że literatura węgierska, w odróżnieniu od polskiej, nie przeżywała w okresie tużpowojennym kryzysu estetycznego, nad Dunajem nie prowadzono dyskusji o „właściwych” formach literatury. Zajmujące mnie dzieła dowodzą, że doświadczenie żydowskie daje się zrelacjonować językiem modernistycznym (Piotrowiak-Junkiert 2020: 22).

To szerokie ujęcie otwiera omówienie książki Rudnóy (1910-1947) - „pierwszej opublikowanej nad Dunajem kobiecej narracji o Auschwitz" (Piotrowiak-Junkiert 2020: 62). Aż do 2011 roku, gdy po 65 latach doczekała się wznowienia, nie funkcjonowała w świadomości czytelniczej i refleksji krytycznej, do dziś

2 Wydane po raz pierwszy jako A piros bicykli (Czerwony rower) w 1947 roku.

3 Wszystkie dane bibliograficzne pochodzą $\mathrm{z}$ analizowanej tutaj pracy Od idylli do ironii... 
zajmując marginalną pozycję. Jak pisze Piotrowiak-Junkiert, książka Rudnóy - będąca przykładem powieści socjograficznej - to jeden „z najciekawszych eksperymentów artystycznych wśród tekstów poświęconych Zagładzie". Inaczej niż w utworach pisarek tworzących bezpośrednio po wojnie (także polskich, spośród których przywołane zostały Seweryna Szmaglewska i Zofia Kossak-Szczucka), w powieści Rudnóy nie znajdziemy dokumentacji wojennej, lagrowej rzeczywistości, katalogowania, objaśniania realiów życia obozowego, ujęcia panoramicznego. Piotrowiak-Junkiert nazywa strategię zastosowaną przez pisarkę „narracją oszczędzającą”: bohaterki nie wracają do negatywnych doświadczeń przeszłości (a więc nie opowiadają o tym, co je spotkało w obozie), bo ich cele ukierunkowane są w stronę przyszłości: zemsty, rozliczenia win. Jednocześnie jednak pamiętają o przeszłości, pragnąc sprawiedliwości, przywrócenia godności ofiarom. Najważniejsza jest kobieca bohaterka, jej podmiotowość, samoświadomość, tożsamość i prawo do zemsty na oprawcach. Jak pokazuje Piotrowiak-Junkiert, powieść czytać trzeba także w odniesieniu do pozatekstowej rzeczywistości, stanowi bowiem autorską odpowiedź Rudnóy na sytuację panującą w powojennych Węgrzech:

Sceny zemsty, które pisarka postanowiła włączyć do książki, traktuję jako jedno z najdobitniejszych przesłań literackich do narodu. To wołanie o dyskusję w świecie, w którym polityka państwowa robiła wszystko, by ,temat żydowski” nie wypływał ani w debatach publicznych, ani społecznych. [...] Rudnóy była jednym z pierwszych i nielicznych twórców, którzy poruszyli problem zupełnego braku odpowiedzi społeczeństwa na zarzut współudziału w Zagładzie, antysemityzmu i polityki historycznej nieuwzględniającej żydowskiego doświadczenia, w tym także praw do odszkodowań, symbolicznych pochówków czy odzyskiwania mienia (Piotrowiak-Junkiert 2020: 85).

Inne niż Rudnóy miejsce w literaturze węgierskiej zajmuje Radnóti (1909-1944), obecny w kanonie, przywoływany w podręcznikach, jednak jako poeta węgierski, nie zaś poeta żydowski, którego tożsamość określiły „ustawy żydowskie" (Piotrowiak-Junkiert 2020: 11). Cenię sposób, w jaki autorka $\mathrm{Od}$ idylli do ironii... opowiada „każdemu czytelnikowi” o tym, kim był Radnóti, jak rysuje postać i biografię, jak omawia jego twórczość, prowadząc do wierszy ostatnich, najbardziej interesujących w kontekście analizowanej tutaj pracy. Nakreślenie tej linii rozwojowej, umieszczenie twórczości poety legendarnego pisma „Nyugat” w szerszej perspektywie pokoleniowej, w sytuacji Żydów węgierskich w pierwszych dekadach XX wieku ma także wymiar etyczny. Polskiemu 
odbiorcy niezwykły wydawać się może fakt, że Radnóti opowiada o wojnie, Marszu Śmierci sięgając po estetykę bukoliczną, pisząc heksametrem - zderza obrazy śmierci z idylliczną scenerią, los człowieka z losem zwierząt (typowych dla estetyki idyllicznej: owiec i wołu, oraz figur owadzich - z innego zgoła porządku). Interpretując Razglednice, Piotrowiak-Junkiert nie tylko sięga ku starożytności, która stanowi oczywiste źródło i kontekst interpretacyjny, ale dostrzega i analizuje obecność zwierząt w tych utworach także w odniesieniu do literatury I wojny światowej czy postantropocentrycznych odczytań literatury zagładowej.

W dwóch kolejnych częściach, jak w tytule pracy, Piotrowiak-Junkiert prowadzi czytelnika od idylli do ironii. Odnajduje ją w powieściowym quasi-pamiętniku Emberszag Szépa (1884-1953), który „jest węgierską odpowiedzią na pytanie, jak funkcjonuje intelektualista w czasach tragedii” (Piotrowiak-Junkiert 2020: 149). W węgierskiej recepcji pominięte zostało wpisane w utwór doświadczenie bycia Żydem w czasie wojny - katastrofa i zmiana, o której w kontekście biografii i twórczości Szépa autorka opowiada wyczerpująco. Emberszag to opowieść świadomego swego losu intelektualisty, łączącego tragiczne rozpoznanie z dystansującą ironią. Czytelnik zostaje wciągnięty w tę opowieść na prawach współodpowiedzialnego towarzysza drogi, obserwatora żydowskiej doli wojennej. Podobnie jak w Razglednicach, obecne są tutaj opisy przyrody, która nie umiera, co widzieć można jako niezgodę na śmierć, którą niesie nazizm.

Doświadczenie powołania do służby pracy i „przymus żydowskości” łączy Szépa nie tylko z Radnótim, ale i z Vasem (1910-1991). Analizowane przez Piotrowiak-Junkiert dzieła Vasa - nieopublikowany dziennik Ostromnapló oraz cykl poetycki Márciustól márciusig - „były nie tylko osobistymi relacjami z codzienności pisarza żydowskiego pochodzenia, ukrywającego się przez nazistami, ale także trenami pisanymi dla ukochanego miasta" (Piotrowiak-Junkiert 2020: 155). Los żydowskiej społeczności Budapesztu, węgierski antysemityzm legły u podstaw wojennego dzieła pisarza, zmieniając charakter jego twórczości na lapidarny i - jak w przypadku Szépa - ironiczny. Tak w dzienniku Ostromnapló, jak i w „wierszowanym dzienniku” Márciustól márciusig, który wydany zostaje w czasie silencium, Vas buduje „intelektualną zaporę, oddzielającą twórcę od nieubłaganego w swym okrucieństwie, ale wciąż postrzeganego z ironią, świata" (Piotrowiak-Junkiert 2020: 163). Ironia, podobnie jak miało to miejsce w przypadku Szépa, pozwala osiągnąć dystans. Co szczególnie interesujące (także w związku z zaskoczeniem, jakie niesie lektura Razglednic Radnótiego), w ostatnich częściach cyklu Vasa „pojawiają się sonet, elegia, gazela, fraszka $\mathrm{i}$ tren napisane $\mathrm{w}$ różnych stopach metrycznych: anapestem, jambem i heksametrem" (Piotrowiak-Junkiert 2020: 166). 
Powrót do kobiecej perspektywy mówienia o Zagładzie przynoszą dwa kolejne rozdziały. Badaczka zaczyna swe rozważania od pytania o miejsce, jakie w korpusie literatury (danego kraju, Europy, świata) zajmują utwory spisane przez kobiety. I dalej, przy pełnej świadomości skomplikowania materii, pyta, jakie miejsce w korpusie tym zajmują utwory pisane przez kobiety, które są Żydówkami (podwójne wykluczenie) i tworzyły na Węgrzech (marginalizacja nie tylko ze względu na płeć autora, ale i temat - ponownie: podwójne wykluczenie). Jak pisze autorka,

teksty prezentujące żydowską perspektywę feministyczną krążyły samotnie po orbitach męskich narracji, wymykając się im tematycznie i nierzadko formalnie, by w końcu, $\mathrm{z}$ powodu braku recepcji, znaleźć się na obrzeżach kanonu i popaść w niebyt, jako narracje źle obecnego tematu (Piotrowiak-Junkiert 2020: 175).

Pierwszym przykładem słuszności tego rozpoznania jest casus przywołanej powyżej powieści obozowej Rudnóy. Przykład drugi stanowi z pewnością proza poetycka Mándy (1918-2001), „jeden z oryginalniejszych tekstów kobiecych poświęconych Zagładzie [...], dzięki któremu zmienił się horyzont literackiej reprezentacji obozów" (Piotrowiak-Junkiert 2020: 176-177). Podobnie jak w przypadku powieści Rudnóy, nie obserwujemy tutaj dominacji faktografii, postawy dokumentującej, które ustępują miejsca surrealistycznej, onirycznej wizji (także śnienia we śnie, o czym świadczy jeden z podtytułów dzieła), pełnej metafor i symboli. Jednocześnie Mándy wypracowuje własny język opowieści o Zagładzie, oparty na wyliczeniach oksymoronów. Jak czytamy w Od idylli do ironii...:

Pisarka celowo wybrała estetykę surrealną, bo jej głównym celem była konfrontacja sztuki ze społeczeństwem odrzucającym tradycyjne formy narracji wojennych, unikającym debaty na temat własnego udziału w wojnie. W obliczu nieprzezwyciężalnego milczenia Mándy wybrała awangardową wyobraźnię, sekretny zapis obrazów zbyt wstrząsających, by odnotować je bez narzędzi literackich. Takie pisanie było formą ratowania samej siebie, osłaniania się przed wiedzą, która niszczyła, ale przede wszystkim czytelnym znakiem literackiego kunsztu (Piotrowiak-Junkiert 2020: 192).

Do innego typu opowieści przenosi nas analiza gettowych dzienników kobiet: Heyman i jej matki Ágnes Zsolt oraz Dévényi Sándorné. Oba pisane 
są w czasie Zagłady, poszczególne wpisy pozostają w ścisłym związku z rozgrywającymi się wydarzeniami - nie ma tutaj miejsca na perspektywę „post”. Pierwszy z dzienników powstał w getcie w Nagyvárad w 1944 roku. Autorką jest trzynastoletnia Éva, która ginie w Auschwitz, po wojnie dziennik opublikowany zostaje przez jej matkę, Ágnes, która prawdopodobnie usunęła niektóre fragmenty przed publikacją. Piotrowiak-Junkiert (za Susan Rubin Suleiman) zalicza dziewczynkę do „generacji 1,5”, czyli tych dzieci, które urodziły się w latach 1920-1943, a więc w czasie wojny miały kilka, kilkanaście lat. Rzeczywistość Zagłady zmusiła je do przedwczesnego dojrzewania, co powoduje, że w ich opowieściach, tak jak ma to miejsce właśnie w dzienniku Heyman, obserwować możemy stałe współistnienie dwóch perspektyw: dziecka i dorosłego. Interesujące jest zestawienie omawianych tutaj zapisków dziewczynki z innymi, wydanymi w Polsce, diariuszami dzieci: Anny Frank, Reni Knoll, Dawida Sierakowiaka, Ryfki Lipszyc, Dawida Rubinowicza czy Rutki Laskier (Piotrowiak-Junkiert 2020: 214).

Autorka drugiego dziennika jest żoną i matką - ma trzynastoletniego syna i oczekuje kolejnego dziecka. Zdając sobie sprawę z zagrożenia, które dotyczy całej jej rodziny, ale także specyfiki własnego położenia, próbuje ze wszystkich sił przygotować się na nieuniknione, zabezpieczyć jak najlepiej na wypadek nagłego pogorszenia sytuacji. Nie znajduje wsparcia w mężu, który „reprezentuje postawę skrajnego pesymizmu, neguje możliwość przetrwania żony, drwi z jej ciąży i podważa wszystkie intuicyjne, czyli bazujące na ocenie emocji, decyzje kobiety" (Piotrowiak-Junkiert 2020: 217). Anna zmuszona zostaje do przejęcia męskich ról społecznych, dla syna staje się nie tylko matką, ale i ojcem. Głównym problemem jest ciąża - to ona stanowi nieprzekraczalną „różnicę egzystencjalną” w położeniu Anny i jej męża. Piotrowiak-Junkiert wskazuje, że inaczej niż w przypadku bohaterek Rudnóy, nie mamy tutaj do czynienia ze strategią solidarnościową, tworzeniem wspólnoty kobiet, ale „z radykalnym gestem separacji”, co stanowi ciekawy kontrapunkt także w kontekście lektury narracji kobiecych opublikowanych w Polsce.

Bohaterem ostatniego rozdziału Od idylli do ironii... jest Örkény, autor reportażu Lágerek népe, poświęconego sowieckiej niewoli, do której pisarz dostał się po walkach w zakolu Donu, gdzie pełnił służbę w drugiej armii węgierskiej. Położenie Żydów - robotników przymusowych - było tragiczne: zmuszani byli do wykonywania najbardziej niebezpiecznych prac, byli bici, głodzeni, źle ubrani, co miało niebagatelne znaczenie, gdy mrozy sięgały czterdziestu stopni. Choć robotnicy przymusowi stanowili połowę ofiar walk nad Donem, nie wspomina się o nich w dyskursie oficjalnym. Piotrowiak-Junkiert komentuje tę sytuację następująco: „Skłonna jestem podejrzewać, że usuwanie danych 
o tożsamości ofiar miało służyć budowaniu narodowego dyskursu wiktymistycznego i zwyczajnie «opłacało się» myślenie o uczestnikach walk w zakolu Donu jako jednorodnej, «węgierskiej» grupie" (Piotrowiak-Junkiert 2020: 229).

Örkény opowiada o realiach życia w obozie jenieckim, nie szczędząc drastycznych szczegółów, artykułuje różnicę w położeniu Żydów i nie-Żydów, a także opisuje relacje między tymi grupami ${ }^{4}$ Właściwie do lat osiemdziesiątych XX wieku w recepcji Lágerek népe pomijano problematykę żydowską. Nieodczytany pozostaje także dramat Voronyezs, który Örkény napisał również podczas pobytu w obozie jenieckim pod Moskwą. Zakryte pozostać miały walki drugiej armii węgierskiej przeciw Rosjanom, choć do dzisiaj tekst nie doczekał się recepcji. Skłonność autora do eksperymentów formalnych znalazła swoje najwyrazistsze odzwierciedlenie w powstałym w obozach w Tambowie i Krasznogorsku zbiorze nowel frontowych Hábroús évek. W utworach tych - obok estetyki groteski i absurdu - Örkény „niestrudzenie poszukując formy, która pomieściłaby pamięć i wiedzę na temat frontu" (Piotrowiak-Junkiert 2020: 261), wykorzystał także ironię.

Praca, jaką wykonała autorka, jest ogromna. Początek swych badań oparła na intuicji, wspartej dobrym rozpoznaniem sytuacji, która panowała w analizowanym okresie na Węgrzech. Odkrycia, których dokonała, zdecydowanie kwestionują aktualny węgierski stan badań nad interesującym ją zagadnieniem. Ponadto wymykają się ,ustaleniom teoretycznym sformułowanym przez światowych badaczy literatury poświęconej Zagładzie" (Piotrowiak-Junkiert 2020: 18).

Opowieść o życiorysie każdego twórcy umieszczona zostaje w rozbudowanym kontekście historycznym. Dowiadujemy się, jak wyglądała „kwestia żydowska" na Węgrzech w przededniu II wojny światowej, Węgry czasu wojny, co działo się z Żydami, jakie decyzje wobec nich podejmowano, jakich represji doznawali, jakie były postawy węgierskiego społeczeństwa. Szeroki jest także kontekst historycznoliteracki - twórczość konkretnych pisarzy widziana jest każdorazowo w perspektywie literatury węgierskiej, europejskiej, światowej. Dużo tutaj odniesień do literatury polskiej, do sytuacji polskiej literatury poświęconej Zagładzie, jej recepcji. Rozpoznanie gatunków, problemów, obszarów doświadczenia, jakie podjęła literatura węgierska, by opowiedzieć o Zagładzie,

4 Zob. np. „okazywało się, że w obozach jenieckich znane z kraju zachowania i reakcje powtarzały się z taką częstotliwością jak w ojczyźnie”, „[w] niewoli, kiedy wydawało się, że uwspólnione doświadczenie i bycie skazanym na współpracę powinno zniwelować wcześniejsze zatargi, kwitł antysemityzm i wrogość wobec innych narodowości”, jednocześnie „[n] ie dawał jednak [Örkény - S.K.] jednoznacznych i ostatecznych diagnoz dotyczących wrogości, a zwłaszcza antysemityzmu" (Piotrowiak-Junkiert 2020: 242). 
pozwala literaturoznawcy na inne spojrzenie na rodzimy zasób literacki. Lekturze towarzyszy nieustannie porównanie i namysł nad możliwymi odniesieniami na gruncie polskim. Te odwołania wywołują, paradoksalnie, poczucie niedosytu - tworzą potrzebę dalszych, głębszych porównań, zwłaszcza w kontekście powstałych w Polsce do końca lat czterdziestych XX wieku utworów pisanych przez twórców pochodzenia żydowskiego, nie zaś kanonicznych tekstów, które po dziś dzień dominują recepcyjnie. To oczywiście zadanie na przyszłość.

Na zakończenie powiedzieć można zatem, że książki takie jak Od idylii do ironii... powstać mogą wtedy, gdy zaistnieje pewna, wcale nieoczywista sytuacja - gdy pojawi się badaczka lub badacz, którego warsztat, przygotowanie merytoryczne, kompetencje językowe pozwalają na przeprowadzenie naukowej analizy literatury obcojęzycznej, jednocześnie zaś umożliwiają odniesienie tych ustaleń do literatury rodzimej - jednak bez szkody dla głównego obszaru badawczych eksploracji. Książkę polecić można każdemu, nie tylko tym, którzy na co dzień zajmują się literaturą poświęconą Zagładzie. Przesuwa horyzont.

\section{| Bibliografia}

Halasi Zoltan (2017), Droga do pustego nieba, przeł. Kinga Piotrowiak-Junkiert, Nisza, Warszawa.

Kertész Imre (2016), Ostatnia gospoda. Zapiski 2001-2009, przeł. Kinga Piotrowiak-Junkiert, W.A.B., Warszawa.

Piotrowiak-Junkiert Kinga (2014), Świadomość zwrócona przeciwko sobie samej. Imre Kertész wobec Zagłady, IBL PAN, Warszawa.

Piotrowiak-Junkiert Kinga (2020), Od idylli do ironii. Literatura wegierska wobec Zagłady w latach 1944-1948, Wydawnictwo Naukowe UAM, Poznań.

Radnóti Miklós (1980), Spienione niebo, wybór, posłowie i przypisy Konrad Sutarski, przeł. Tadeusz Nowak i in., Wydawnictwo Literackie, Kraków. Röhrig Géza (2016), Oskubana papuga Rebego. Zmyślone opowieści chasydzkie, przeł. Kinga Piotrowiak-Junkiert, Austeria, Kraków.

Steinlauf Michael C. (2001), Pamięć nieprzyswojona. Polska pamięć Zagłady, przeł. Agata Tomaszewska, Cyklady, Warszawa.

Szép Ernő (2017), Woń człowieka, przeł. Łukasz Woiński, „Zeszyty Literackie”, nr 2, s. 14-25. 


\section{| Abstrakt}

SylWia KarolaK

„Luki historii domagają się domknięcia, a przede wszystkim opisania”. Literatura węgierska wobec Zagłady w latach 1944-1948

Autorka omawia książkę Kingi Piotrowiak-Junkiert, Od idylli do ironii. Literatura wegierska wobec Zagłady w latach 1944-1948 (Wydawnictwo Naukowe UAM, Poznań 2020).

Słowa kluczowe: Holokaust, II wojna światowa, literatura, idylla, ironia, Węgry, Polska

\section{| Abstract \\ SylWia Karolak \\ "The Gaps in History Need to be Closed and, Above All, Described": Hungarian Literature on the Holocaust between 1944-1948}

The author discusses Kinga Piotrowiak-Junkiert's book From Idyll to Irony. Hungarian Literature on the Holocaust between 1944-1948 (Adam Mickiewicz University Press, Poznan 2020).

Keywords: Holocaust, The Second World War, literature, idyll, irony, Hungary, Poland

\section{| Biogram}

Sylwia Karolak - dr, literaturoznawczyni, adiunktka w Instytucie Filologii Polskiej UAM w Poznaniu. Autorka monografii Doświadczenie Zagłady w literaturze polskiej 1947-1991. Kanon, który nie powstał (Poznań 2014) oraz Sporów o Kamienie na szaniec Aleksandra Kamińskiego (Poznań 2019). Współredaktorka pracy zbiorowej Ślady II wojny światowej i Zagłady w najnowszej literaturze polskiej (Poznań 2016), Ameryki Barańczaka (Kraków 2018), tomów Stulecia poznańskiej polonistyki (1919-2019) (Poznań 2018-2019). Publikowała w „Czasie Kultury”, „Poznańskich Studiach Polonistycznych”, „Slavii Occidentalis”, „Politei”, „Polonistyce”, a także wielu tomach zbiorowych.

E-mail: skarolak@amu.edu.pl

ORCID: 0000-0002-2438-4577 